\title{
Soft-coral natural chimerism: a window in ontogeny allows the creation of entities comprised of incongruous parts
}

\author{
Yael Barki ${ }^{1,2}$, Daniel Gateño ${ }^{1}$, Dan Graur ${ }^{2}$, Baruch Rinkevich ${ }^{1, *}$ \\ ${ }^{1}$ Minerva Center for Marine Invertebrate Immunology and Developmental Biology, National Institute of Oceanography, \\ Israel Oceanographic \& Limnological Research, PO Box 8030, Haifa 31080, Israel \\ ${ }^{2}$ Department of Zoology, Tel Aviv University, Ramat Aviv 69978, Israel
}

\begin{abstract}
Chimerism, the evolutionary perplexing outcome of fusion between conspecific individuals, is widely documented in nature. Several reports assign a variety of benefits to the state of chimerism, especially in cases of fusions between kins, rating a chimera as a congruous entity. For the first time, we describe here a follow-up study on chimeras of soft corals that occur only between ontogenetically immature conspecifics, prior to development of a histocompatibility recognition system. Four soft coral species from the Red Sea were investigated: Nephthea sp., Heteroxenia fuscescens, Parerythropodium fulvum fulvum and Clavularia hamra. Co-settlement of planulae resulted in high frequencies of spontaneous allogenic fusions between primary polyps. Tissue fusion between allogenic partners was confirmed histologically. During the observation periods (up to $450 \mathrm{~d}$ ) chimeras were detached, or chimerism resulted in the death of 1 or more partners, or in morphological resorption of the partners. The results also document slower growth and growthretarding disorders such as disruption of the structural patterns of polyp budding and polyp configuration. These cumulative effects were only manifested by individuals comprised of incongruous components. Such chimeras are likely to be less suited to field conditions than genetically homogeneous individuals, raising the ecological-evolutionary question of why soft-coral chimeras arose in the first place. We propose that juvenile cnidarian chimerism represents a case in which ontogenetic allorecognition is not infallible, and that it is further promoted by the gregarious settlement of larvae characteristic of many coral species.
\end{abstract}

KEY WORDS: Allorecognition $\cdot$ Chimeras $\cdot$ Eilat $\cdot$ Evolution $\cdot$ Soft corals

\section{INTRODUCTION}

Natural chimerism is a common phenomenon in the wild, and chimeras have been documented from more than 9 phyla of protists, fungi, plants and animals (Buss 1982). Scientific literature assigns many benefits to chimerism, the most significant being increased body size and consequent improvement in survival, growth rate and reproductive output (Buss 1982, Grosberg

\footnotetext{
*Corresponding author. E-mail: buki@ocean.org.il
}

\& Quinn 1986, Grosberg 1988). However, benefits of chimerism have been recorded only in primitive organisms such as slime molds and algae (Rinkevich 1996: review, Rinkevich \& Shapira 1999). All other results obtained for colonial marine organisms, including sponges, cnidarians and tunicates (although in many cases not critically examined) revealed only disadvantages of chimerism (Rinkevich 1996). The convergent evolutionary routes that shape natural chimerism in so many organisms, including mammals (Bernischke \& Kaufmann 1990) are therefore of great scientific interest (Buss 1982, Grosberg \& Quinn 1986, Rinkevich 1996). 
Results of a recent study (Frank et al. 1997) documented natural chimerism in the scleractinian coral Stylophora pistillata within an ontogenetic window of only 4 mo post-metamorphosis. Earlier, Hidaka (1985) performed primary polyp fusion assays on offspring originating from rejecting Pocillopora damicornis adults. To evaluate the possible existence of an ontogenetic window that allows the development of natural chimeras in other members of cnidarians, we investigated allogenic responses in juveniles and adults of 4 soft coral species from the Red Sea, Clavularia hamra, Nepthea sp., Heteroxenia fuscescens and Parerythropodium fulvum fulvum. Although tissue fusions have never been recorded during numerous allogenic assays of adult colonies in the field or under laboratory conditions (Frank et al. 1996, Barki 1999), we found that planula larvae and young $(<3 \mathrm{mo})$ polyps of all the above alcyonarian species can spontaneously fuse upon contact, forming natural chimeras. Fusions occurred either between kin larvae and young polyps originating from the same mother colony or between juveniles released from different genotypes (Barki 1999). Natural chimeras were also recorded in situ during field observations (Barki 1999), raising the question of the evolutionary significance of chimerism in general (Buss 1982, Grosberg \& Quinn 1986, Rinkevich 1996), and in particular of chimerism restricted to early ontogenetic stages (Frank et al. 1996, 1997, Barki 1999).

To evaluate the ecological and biological consequences of young-colony fusions in the Alcyonacea, we followed chimeras arising from allogenic fusions between juveniles of the 4 soft coral species listed above. To reduce the possible costs for chimerism, we selected chimeras formed by fusion of siblings (colonies originating from a single hatch of the same maternal colony). We describe allogenic fusions between sibling primary polyps, and evaluate the morphological effects of chimera formation. The morphological effects of chimerism and the growth rates of chimeric colonies are compared with data for non-chimeric colonies.

\section{MATERIALS AND METHODS}

Planulae collection. Embryos and planulae of the 4 soft coral species Parerythropodium fulvum fulvum, Clavularia hamra, Heteroxenia fuscescens and Nephthea sp. were collected from gravid colonies in the northern Gulf of Eilat, mainly in front of the H. Steinitz Marine Biological Laboratory (MBL) at Eilat. They were shipped in $50 \mathrm{ml}$ plastic tubes containing filtered seawater to the laboratory in Haifa within $4 \mathrm{~d}$ of collection. Each plastic tube contained embryos/larvae from a single colony only.
Parerythropodium fulvum fulvum: This is an encrusting species. It is a gonochoric surface brooder in which embryogenesis takes place on the surface of female colonies in a mucoid suspension over almost 2 mo (end of June until beginning of August). The nonsymbiotic planulae complete their development within $6 \mathrm{~d}$ of fertilization (Benayahu \& Loya 1983). Embryos of $P$. f. fulvum were collected from 11 mother colonies on July 25, 1995, at a depth of 4 to $8 \mathrm{~m}$, in front of the MBL at Eilat. Within $5 \mathrm{~d}$ of collection, all embryos developed into mature planulae.

Clavularia hamra: Also an encrusting coral species, C. hamra inhabits shallow waters of the Red Sea. It has a reproductive pattern similar to Parerythropodium fulvum fulvum, during a short period in summer. The non-symbiotic planulae complete their development within $6 \mathrm{~d}$ of fertilization (Benayahu 1989). Embryos of C. hamra were collected from the surface of a single mother colony on July 31, 1996, at a depth of $0.5 \mathrm{~m}$, north of the MBL at Eilat. Embryos developed into mature planulae within $6 \mathrm{~d}$ of collection.

Heteroxenia fuscescens: This species is a hermaphrodite brooder that releases non-symbiotic planulae year-round on Eilat reefs (Achituv \& Benayahu 1990). Colonies of $H$. fuscescens were collected on the coral reef, between 3 and $8 \mathrm{~m}$ depth, in front of the MBL at Eilat, during May to August 1995. The colonies were placed in running seawater containers and (prior to sunset) each colony was separately transferred overnight to a static aerated tank (3.3 l). The released planulae were collected the following morning with pipettes.

Nephthea sp.: This arborescent soft coral is a gonochoric brooder that releases zooxanthellate planulae during the summer (Ben-David Zaslow 1994). Small fragments (5 to $10 \mathrm{~cm}$ ) were collected during the reproductive season from Big Routa at Sinai $\left(29^{\circ} 11^{\prime} 00^{\prime \prime} \mathrm{N}\right.$, $34^{\circ} 43^{\prime} 45^{\prime \prime}$ E) in 1994 and from the Coral Reef Nature Reserve at Eilat in 1994, 1995 and 1996. Each branch was held in an aerated tank $(3.3$ l) at the MBL overnight and the released planulae were collected the next morning. Branches used on more than one night were placed during the day in containers with running seawater and prior to sunset were transferred to aerated aquaria as described by Ben-David Zaslow (1994).

Allogenic fusions. Sibling planulae released from the same maternal colony were placed in petri dishes. In some of the dishes we put freshly collected small stones covered by organic matter. Different numbers of kin planulae, according to the number of planulae in a hatch (100 to 200 planulae for Parerythropodium fulvum fulvum, 100 planulae for Clavularia hamra, 30 to 50 planulae for Heteroxenia fuscescens and 12 to 100 planulae for Nephthea sp.) were placed in each dish. 
The planulae were kept with unfiltered seawater $\left(25^{\circ} \mathrm{C}, 24 \mathrm{~h}\right.$ constant light). Water was changed every $48 \mathrm{~h}$. Under these conditions, many planulae settled and metamorphosed to primary polyps within $14 \mathrm{~d}$. After planulae settlement and metamorphosis, the dishes and stones were transferred to aquaria with running seawater (described in Gateño et al. 2000). Polyps were fed twice a day with artificial plankton. Colonies that fused were observed and photographed under a stereoscopic microscope.

The survivorship of chimeric and non-chimeric entities were studied in Nephthea sp. and Heteroxenia fuscescens (daily for the first 2 mo, once a week thereafter). Under our laboratory conditions, only the primary polyps of Nephthea sp. budded additional polyps and grew well, enabling us to follow the rates and patterns of growth of chimeras and non-chimeric individuals for up to $450 \mathrm{~d}$. Statistical analyses included ANOVA, and Student's $t$-tests.

Histology. Fused polyps of the 4 species (young chimeras immediately after fusion to $1 \mathrm{yr}$ after fusion) were fixed in $2.5 \%$ glutaraldhyde in filtered seawater for $24 \mathrm{~h}$ at $4{ }^{\circ} \mathrm{C}$. Samples were rinsed, dehydrated in a graded ethanol series, and embedded in glycol methacrylate plastic (JB-4, Polysciences) in accordance with the manufacturer's specifications). Sections (3 to $5 \mu \mathrm{m}$ ) were obtained with glass knives, stained with hematoxylin and eosin (Bancroft \& Stevens 1990), and mounted on Permount (Fisher Scientific).

\section{RESULTS}

Gregarious settlement resulted in high frequencies of allogenic tissue-to-tissue contacts and led to true morphological fusion within a few days. These morphological fusions were visible in histological sections as continuous layers of ectodermal and endodermal tissues between the allogenic partners (Fig. 1) in all 4 species. There was no sign of cytotoxicity or the formation of a border line between partners up to 15 mo after chimera establishment (the follow-up period of this study).
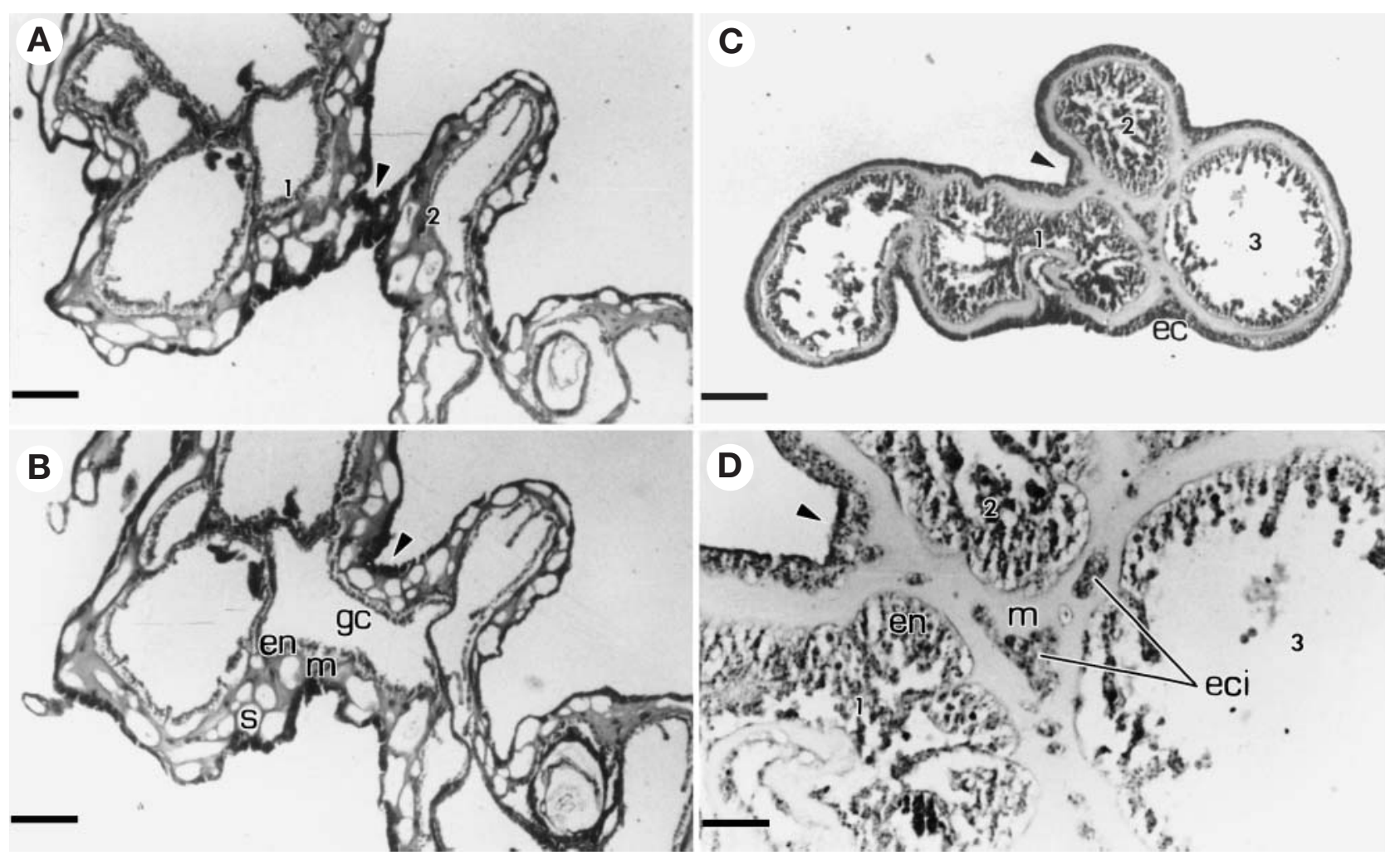

Fig. 1. Histological sections of chimerical entities. (A,B) Nephthea sp.; chimera of 2 partners (1 and 2) at the age of 1 yr; just above the fused region between the partners (A) and within the fused region (B); partners are connected by a continuous epidermis mesoglea (m) and gastrodermis (en) and share the same gastrovascular cavity (gc); the spiculae (s) in the fused region are uniformly distributed. (C,D) Clavularia hamra chimera formed by the fusion of 3 partners $(1,2$ and 3$)$ at the age of 45 ; (C) at the fused region, showing partners connected by a continuous epidermis (ec) and mesoglea; (D) close-up, showing connected mesoglea (m) and cell islands (eci) of epidermis at the plane of fusion. Arrowheads point to the plane of fusion. Scale bars $=250 \mu \mathrm{m}$ in $\mathrm{A}, \mathrm{B}$ and $\mathrm{C}, 25 \mu \mathrm{m}$ in D 
Table 1. Major effects of chimerism in the 4 coral species studied

\begin{tabular}{|c|c|c|c|c|c|c|c|}
\hline $\begin{array}{l}\text { Species } \\
\text { (observational } \\
\text { period) }\end{array}$ & $\begin{array}{l}\text { No. of partners } \\
\text { in a chimera }\end{array}$ & $\begin{array}{l}\text { No. of } \\
\text { chimeras }\end{array}$ & $\begin{array}{l}\text { Total no. } \\
\text { of partners }\end{array}$ & $\begin{array}{l}\text { Percenta } \\
\text { separated } \\
\text { (n) }\end{array}$ & $\begin{array}{l}\text { died of part } \\
\text { died } \\
\text { (n) }\end{array}$ & $\begin{array}{l}\text { ers that: } \\
\text { resorbed } \\
\text { (n) }\end{array}$ & $\begin{array}{l}\% \text { unsuccessful } \\
\text { partners } \\
\text { in chimera }\end{array}$ \\
\hline $\begin{array}{l}\text { Nephthea sp. } \\
\text { (450 d) }\end{array}$ & $\begin{array}{l}2 \\
3 \\
4 \\
5\end{array}$ & $\begin{array}{c}17 \\
4 \\
2 \\
2\end{array}$ & $\begin{array}{c}34 \\
12 \\
8 \\
10\end{array}$ & $\begin{array}{l}11.8(4) \\
0(0) \\
0(0) \\
10.0(1)\end{array}$ & $\begin{array}{c}8.8(3) \\
8.3(1) \\
25.0(2) \\
40.0(4)\end{array}$ & $\begin{array}{c}8.8(3) \\
33.3(4) \\
0(0) \\
10.0(1)\end{array}$ & $\begin{array}{l}29.4(10) \\
41.7(5) \\
25.0(2) \\
60.0(6)\end{array}$ \\
\hline $\begin{array}{l}\text { Total }(\mathrm{n}) \\
\% \text { of partners }\end{array}$ & & 25 & 64 & $\begin{array}{c}5 \\
7.8\end{array}$ & $\begin{array}{c}10 \\
15.6\end{array}$ & $\begin{array}{c}8 \\
12.5\end{array}$ & $\begin{array}{c}23 \\
32.8\end{array}$ \\
\hline $\begin{array}{l}\text { Heteroxenia } \\
\text { fuscescens } \\
(75 \mathrm{~d})\end{array}$ & $\begin{array}{l}2 \\
3 \\
4\end{array}$ & $\begin{array}{l}7 \\
3 \\
1\end{array}$ & $\begin{array}{c}14 \\
9 \\
4\end{array}$ & $\begin{array}{c}0(0) \\
22.2(2) \\
0(0)\end{array}$ & $\begin{array}{l}0(0) \\
0(0) \\
0(0)\end{array}$ & $\begin{array}{l}7.1(1) \\
0(0) \\
0(0)\end{array}$ & $\begin{array}{c}7.1(1) \\
22.2(2) \\
0(0)\end{array}$ \\
\hline $\begin{array}{l}\text { Total }(\mathrm{n}) \\
\% \text { of partners }\end{array}$ & & 11 & 27 & $\begin{array}{c}2 \\
7.4\end{array}$ & $\begin{array}{l}0 \\
0\end{array}$ & $\begin{array}{c}1 \\
3.7\end{array}$ & $\begin{array}{c}3 \\
11.1\end{array}$ \\
\hline $\begin{array}{l}\text { Parerythropodium } \\
\text { fulvum fulvum } \\
(100 \mathrm{~d})\end{array}$ & $\begin{array}{l}2 \\
3 \\
4 \\
5\end{array}$ & $\begin{array}{l}31 \\
6 \\
2 \\
2\end{array}$ & $\begin{array}{c}62 \\
18 \\
8 \\
10\end{array}$ & $\begin{array}{c}11.3(7) \\
11.1(2) \\
25.0(2) \\
0(0)\end{array}$ & $\begin{array}{c}6.5(4) \\
0(0) \\
0(0) \\
30.0(3)\end{array}$ & $\begin{array}{l}0(0) \\
0(0) \\
0(0) \\
0(0)\end{array}$ & $\begin{array}{l}17.7(11) \\
11.1(2) \\
25.0(2) \\
30.0(3)\end{array}$ \\
\hline $\begin{array}{l}\text { Total }(\mathrm{n}) \\
\% \text { of partners }\end{array}$ & & 41 & 98 & $\begin{array}{c}11 \\
11.2\end{array}$ & $\begin{array}{c}7 \\
7.1\end{array}$ & $\begin{array}{l}0 \\
0\end{array}$ & $\begin{array}{c}18 \\
18.3\end{array}$ \\
\hline $\begin{array}{l}\text { Clavularia hamra } \\
\text { (307 d) }\end{array}$ & $\begin{array}{c}2 \\
3 \\
4 \\
5 \\
6 \\
7 \\
10 \\
17\end{array}$ & $\begin{array}{l}4 \\
1 \\
3 \\
2 \\
1 \\
1 \\
1 \\
1\end{array}$ & $\begin{array}{c}8 \\
3 \\
12 \\
10 \\
6 \\
7 \\
10 \\
17\end{array}$ & $\begin{array}{c}25.0(2) \\
0(0) \\
58.3(7) \\
20.0(2) \\
16.7(1) \\
0(0) \\
10.0(1) \\
0(0)\end{array}$ & $\begin{array}{c}12.5(1) \\
0(0) \\
16.6(2) \\
50.0(5) \\
66.7(4) \\
14.3(1) \\
60.0(6) \\
52.9(9)\end{array}$ & $\begin{array}{c}0(0) \\
0(0) \\
0(0) \\
0(0) \\
0(0) \\
42.8(3) \\
20.0(2) \\
0(0)\end{array}$ & $\begin{array}{c}37.5(3) \\
0(0) \\
75.0(9) \\
70.0(7) \\
83.3(5) \\
57.1(4) \\
90.0(9) \\
52.9(9)\end{array}$ \\
\hline $\begin{array}{l}\text { Total }(\mathrm{n}) \\
\% \text { of partners }\end{array}$ & & 14 & 73 & $\begin{array}{c}13 \\
17.8\end{array}$ & $\begin{array}{c}28 \\
38.3\end{array}$ & $\begin{array}{c}5 \\
6.8\end{array}$ & $\begin{array}{c}46 \\
62.9\end{array}$ \\
\hline
\end{tabular}

Ninety-one chimeras, each composed of 2 to 17 allogenic partners (totaling 262 genotypes) were investigated $>75 \mathrm{~d}$ for Heteroxenia fuscescens and $450 \mathrm{~d}$ for Nephthea sp. (Table 1). Most of the fusions occurred within less than 1 mo after settlement, ranging on average between $5 \pm 1 \mathrm{~d}$ for $H$. fuscescence and $21.6 \pm 5.7 \mathrm{~d}$ for Clavularia hamra (Table 2). Fusions between polyps occurred in the lower part of the polyp stalk, forming colonial patterns that differed from those of nonchimeric individuals. As a result, in most fusions, it was easy to distinguish morphologically between the partners of the chimera although the original line of fusion between them was not detectable (Fig. 2).

During follow-up observations on chimeras, 3 main morphological effects (Table 1) were recorded: (1) Morphological separation of the partners of a chimera: continuous narrowing of the fused tissue connecting the partners of the union until their complete separation (Figs. 2e,f \& 3). (2) Sudden death of 1 or more partners of a chimera, which did not affect other partners (Fig. 3). (3) Unilateral or reciprocal resorption of polyps, leading to the morphological disapperance of some partners from the chimeras (Figs. $3 \& 4$ ). We classify these effects as detrimental.

The time course of the adverse effects differed (Table 2). In most cases (with the exception of Clavularia hamra), a partner's 'separation' and 'death' occurred within the first 2 mo after fusion, while complete resorption was a much longer process. Nephthea sp. is a typical case. This species was observed over the longest period, and was the only species to develop additional polyps under ex situ conditions. Chimerical separation and a partner's death were completed within the first 2 mo (average of $32.6+26.1$ and $28.8+$ $24.7 \mathrm{~d}$, respectively); after this period no more cases were documented. On the other hand, complete unilateral resorption of 6 partners in chimeras of this species took $>1$ yr (on average $>7$ mo $(211.5+135.5 \mathrm{~d}$; $\mathrm{p}<0.05)$. Moreover, reciprocal resorption of all partners of specific chimeras, although developing slowly, was not completed by the end of this experiment (450 d; Tables 1 \& 2). 

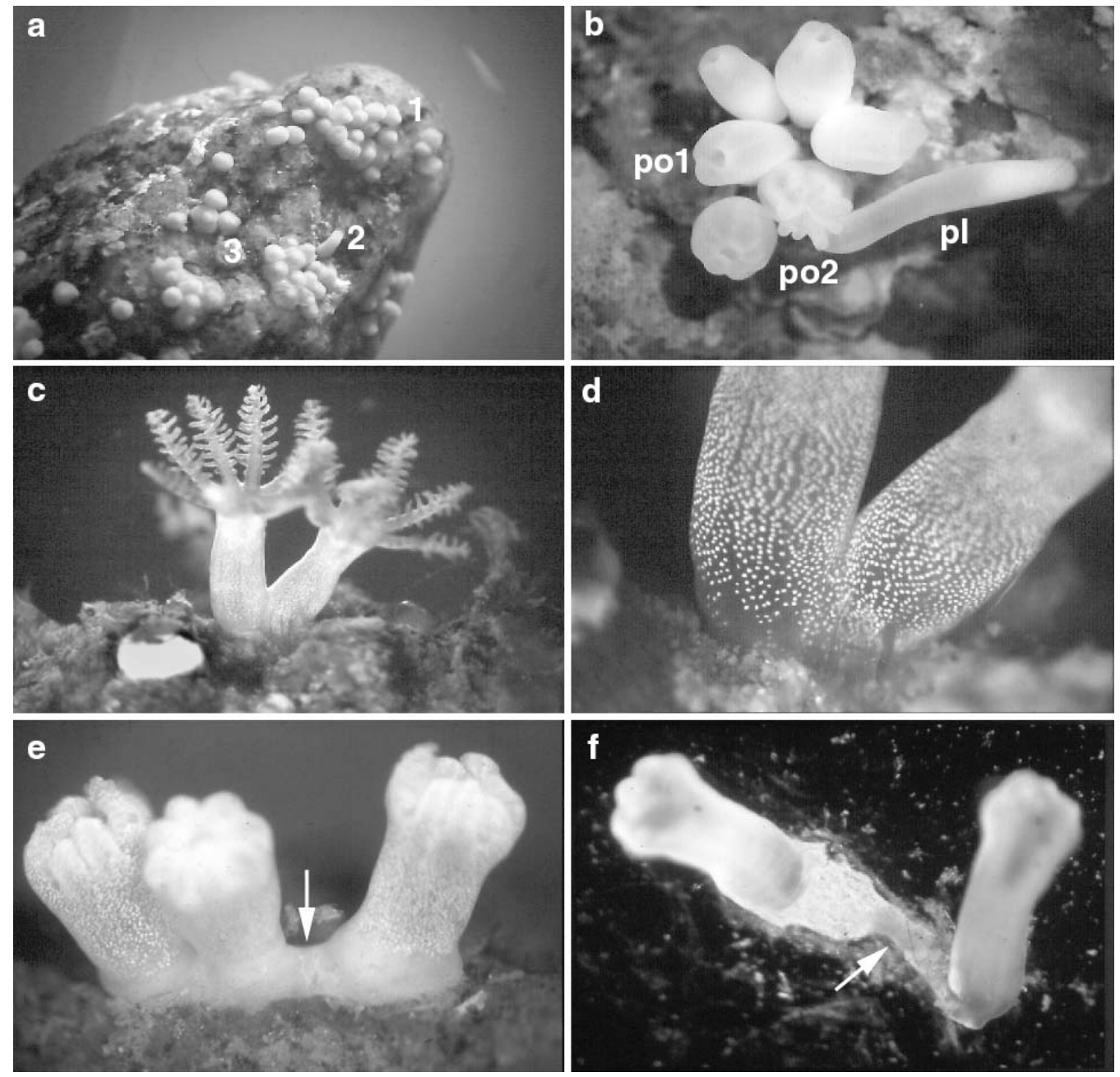

Fig. 2. Chimera formation in soft corals. (a) Gregarious settlement of Clavularia hamra planulae (1 to 3 are aggregates) resulting in the production of multi-chimeras. (b) Gregarious settlement of Heteroxenia fuscescens planulae. pl: planula; po1: planulae metamorphosis to primary polyps with open mouths; po2: planula metamorphosing to primary polyp with open mouth and unpinnated tentacles. (c,d) H. fuscescens chimera, in nature, formed by the fusion of 2 primary polyps; (d) is a close-up of the fusion region. (e) Fusion of $3 \mathrm{H}$. fuscescens primary polyps; arrow points to stolon connecting the 2 non-attached polyps. (f) Narrowing of the connective tissue between 2 partners in Parerythropodium fulvum fulvum chimera

Table 2. Timetable of allogenic responses in chimeras of the 4 coral species

\begin{tabular}{|c|c|c|c|c|}
\hline \multirow[t]{2}{*}{ Species } & \multirow[t]{2}{*}{$\begin{array}{c}\text { Mean fusion time } \\
\text { (days after settlement) }\end{array}$} & \multicolumn{3}{|c|}{$\begin{array}{c}\text { Average period } \\
-\left(\bar{X} \pm \mathrm{SD}_{\text {; days }} \text { after fusion }\right) \text { for: } \\
\end{array}$} \\
\hline & & separation & death & complete resorption \\
\hline Nephthea sp. & $\begin{array}{l}10.6 \pm 19.4 \\
(\mathrm{n}=25)\end{array}$ & $\begin{array}{c}32.6 \pm 26.1 \\
(\mathrm{n}=5)\end{array}$ & $\begin{array}{c}28.8 \pm 24.7 \\
(\mathrm{n}=10)\end{array}$ & $\begin{array}{c}211.5 \pm 135.5 \\
(\mathrm{n}=6)^{\mathrm{a}}\end{array}$ \\
\hline Heteroxenia fuscescens & $\begin{array}{c}5 \pm 1 \\
(\mathrm{n}=11)\end{array}$ & $\begin{array}{c}5.5 \pm 0.7 \\
(\mathrm{n}=2)\end{array}$ & - & $\begin{array}{c}66 \\
(\mathrm{n}=1)\end{array}$ \\
\hline Parerythropodium fulvum fulvum & $\begin{array}{c}16.7 \pm 6.5 \\
(\mathrm{n}=41)\end{array}$ & $\begin{array}{l}11 \pm 8.7 \\
(\mathrm{n}=11)\end{array}$ & $\begin{array}{l}10.7 \pm 7.4 \\
(\mathrm{n}=7)\end{array}$ & - \\
\hline Clavularia hamra & $\begin{array}{l}21.6 \pm 5.7 \\
(\mathrm{n}=14)\end{array}$ & $\begin{array}{c}66.7 \pm 44.5 \\
(\mathrm{n}=13)\end{array}$ & $\begin{array}{c}76.4 \pm 70.0 \\
(\mathrm{n}=28)\end{array}$ & $\begin{array}{c}33.8 \pm 20.3 \\
(\mathrm{n}=5)\end{array}$ \\
\hline
\end{tabular}




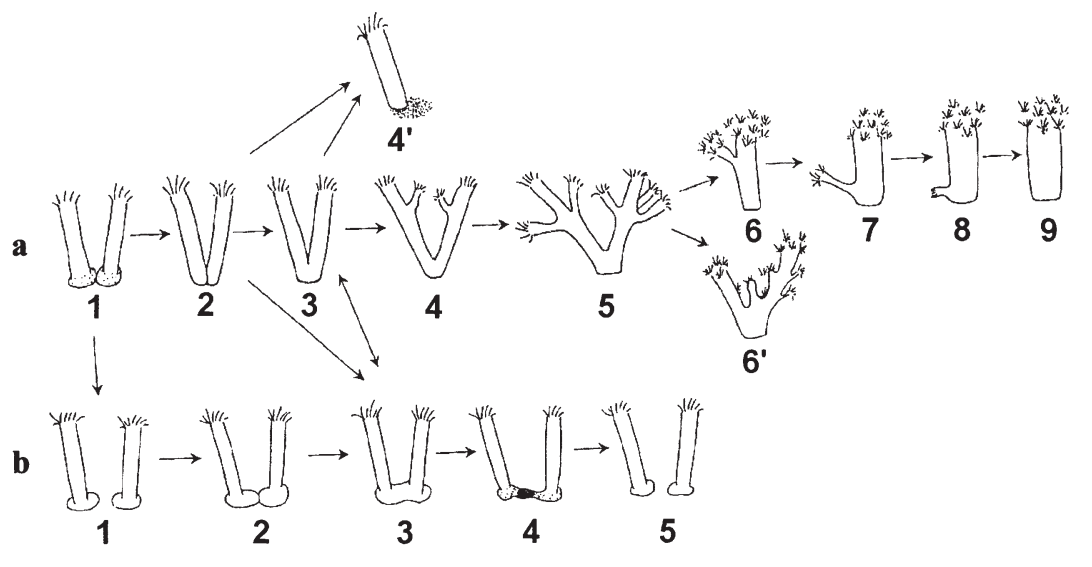

Fig. 3. Allogenic responses in bi-chimeras of the 4 soft coral species examined. (a) Chimerical death and resorption: attached polyps (a1) begin to fuse (a2), forming a chimera (a3) that continues to develop (a4); in some cases, 1 of the partners suddenly dies ( $\left.\mathrm{a} 4^{\prime}\right)$; in the surviving chimeras, 1 partner always grows faster (a5). (a6) At this stage both partners share a common stalk; 1 is significantly larger; in some cases, it is impossible to distinguish between partners $\left(\mathrm{a} 6^{\prime}\right)$. (a7) to (a9) Final stages leading to complete resorption of 1 partner. (b) Major steps in chimera formation via the stolon (b1) to (b3) and subsequent separation (b4) and (b5)

\section{Parerythropodium fulvum fulvum}

Around $75 \%$ of the attached polyps ( $\mathrm{n}=98$ genotypes) fused within 1 mo. Subsequent contacts did not result in fusion. Primary polyps fused to form 41 chimeras of 2 to 5 partners each (Table 1). Most fusions $(80 \%)$ were between primary polyps in direct tissue contact. However, in $20 \%$ of cases, fusions developed through specially developed stolons (Fig. 3) between non-attached polyps that had settled a few millimeters from each other (maximum $5 \mathrm{~mm}$ ). The stolons were composed of both epithelial layers, an extension of the coenenchyme with a gastrovascular channel in the center (histological study, data not shown). We also observed movement of free cells within the common channel from one partner to the other. Similar stolons were formed during the 'separation' process (Fig. 2f). Separation of the chimeric partners occurred in $11.2 \%$ of the fused genotypes 6 to $15 \mathrm{~d}$ after fusion (Tables 1 \& 2 ). The death of 1 or more partners of the chimera occurred in 5 chimeras and was expressed in 7 genotypes $(7.1 \%)$ within $22 \mathrm{~d}$ after fusion. The primary polyps did not grow well under laboratory conditions and $90 \%$ (fused and control) survived up to $60 \mathrm{~d}$ only.

\section{Clavularia hamra}

Most of the planulae $(85 \%, \mathrm{n}=93)$ settled in aggregates of 2 to 22 planulae each and metamorphosed to primary polyps that were in contact or were very close to each other (Fig. 2a). This gregarious settlement resulted in very high frequency of fusions $(78 \%)$ between the settled polyps within $<1$ mo. Contacting polyps fused to form 14 chimeras, comprised of 2 to 17 partners each, totaling 73 partners in all (Table 1). In 8 chimeras (13 genotypes), 1 or more partners were separated from the chimera (Table 1). Detachment was slow, and was recorded over the entire observation period $(66.7 \pm 44.5 \mathrm{~d}$ : Table 2$)$. One of the main reasons for this separation was the non-specific loss of the tissue connecting the partners as a result of algal settlement and overgrowth. This process was only recorded in Clavularia hamra. (Detachments in other species were not related to non-specific causes, since a skrinking of the contact area was typically recorded). Resorption was recorded in 2 chimeras comprising 7 and 10 partners each (Table 1) 19 to 56 d after fusion. During the observation period of $307 \mathrm{~d}$, budding of additional polyps occurred in only 2 partners within the chimeras and in 2 control genotypes.

\section{Heteroxenia fuscescens}

Within $6 \mathrm{~d}$ of settlement, only $\sim 40 \%$ of the attached polyps ( $\mathrm{n}=27$ ) had fused, forming 11 chimeras of 2 to 4 partners each (Tables 1 \& 2). As in Parerythropodium fulvum fulvum, fusions occurred between polyps in tissue-to-tissue contact (9 chimeras) and between nonattached genotypes that produced stolons (2 chimeras: Fig. 2e). In 2 chimeras, fused genotypes separated into distinct individuals 6 and $10 \mathrm{~d}$ after fusion. In another case, 1 of the partners in the chimera resorbed its confrere $66 \mathrm{~d}$ after fusion. Survivorship under ex situ conditions was very low and $90 \%(n=427)$ of the primary polyps died within the first month. However, there was no significant difference in the survival rate of the chimeric individuals compared to the controls $(\mathrm{p}>$ $0.05, t$-test).

\section{Nephthea sp.}

Approximately $90 \%$ of the individuals in contact (64 genotypes) fused to form 25 chimeras of 2 to 5 partners each (Table 1). We used 55 control individuals. Fusions began in the lowest part of the polyp stalk, except in 
1 case, where fusion occurred along the entire stalk of 2 primary polyps. This chimera did not bud any additional polyp; it developed retarded tentacles and died after $16 \mathrm{~d}$
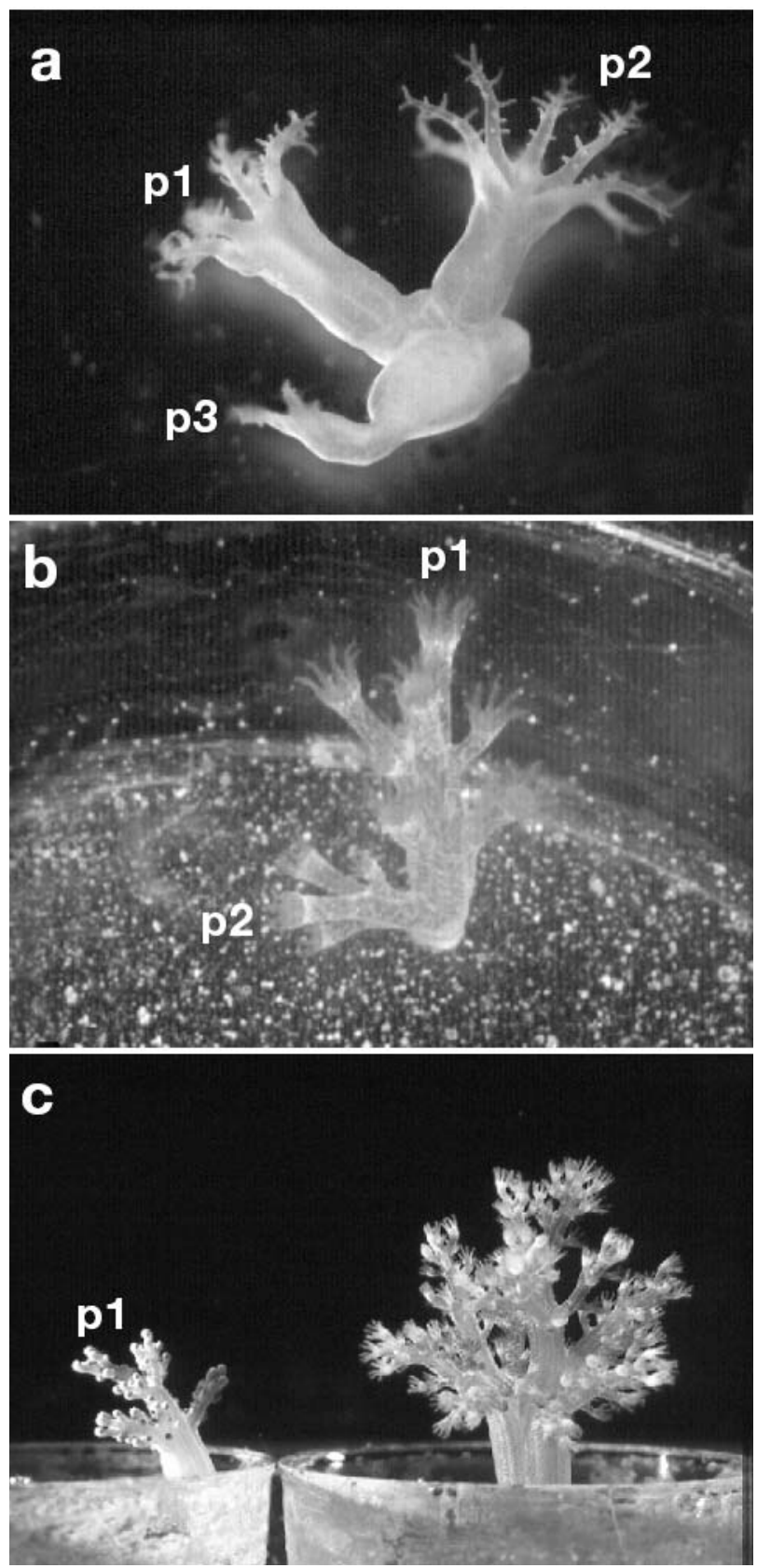

Fig. 4. Nephtea sp. Chimera colony comprised of the fusion of 3 partners. (a) Chimera immediately after fusion, 1 partner (p3) has been partially resorbed. (b) The same chimera 6 mo after full resorption of p3; Partner No. 1 (p1) is larger than Partner No. 2 (p2). (c) On the left: the same chimera 15 mo after fullresorption of $\mathrm{p} 2$; on the right: control colony of the same age
Fusion between individuals usually occurred within $14 \mathrm{~d}$ of settlement, but was recorded up to the age of 3 mo. Chimerism caused instability in the allogenic unions. More than one-third of the genotypes involved in the chimeras and $>80 \%$ of chimerical entities underwent morphological changes leading to separation of partners $(7.8 \%)$, to the sudden death of 1 or more partners $(15.6 \%$; the other partners were not affected) and to unilateral or reciprocal morphological resorption $(12.5 \%$ : Table 1). The time course of these adverse effects differed. While chimerical separation and a partner's death were relatively short-term processes that, on average, were completed within the first month, complete resorption of 1 of the partners took on average $>7$ mo $(p<0.05$; Table 2$)$.

The chimerical processes involved several morphological abnormalities (Figs. $3 \& 4$ ). In all chimeras, the typical arborescent structure of polyp budding was disrupted, and unusual colony patterning developed in forms never observed in nature. In addition, most chimerical colonies had fewer than the typical number of 8 tentacles per polyp, and non-pinnated tentacles developed. These abnormalities in polyp morphology were the first signs of colony resorption. Resorption of polyps led to complete or extensive somatic tissue resorption of a total of 8 partners in 5 chimerical entities (12.5\% of genotypes: Table 1$)$. Resorption of polyps is a gradual process, starting with disappearance of the tentacles, and continuing with the closing of the polyp's mouth and ultimate degradation (with no sign of necrosis) of the entire polyp body including the stem. Small colonies comprised of a single polyp were completely resorbed, sometimes within $<1$ mo after fusion.

Five chimeras (20\%) and 11 non-chimerical individuals $(20 \%)$ survived until the end of the experiment (450 d). Survivorship of the chimeras was therefore similar to that of controls $(p>0.05)$. Chimeric entities were, however, on average larger than nonchimerical colonies immediately after fusion and until Day 65 ( $t$-test; $\mathrm{p}<0.05$; Fig. 5). There was no significant difference in size between the 2 groups until Day 125, after which non-chimerical colonies became significantly larger ( $t$-test; $\mathrm{p}<0.05)$. For example, at age $60 \mathrm{~d}$, chimeric entities had an average of 4.9 polyps $(\mathrm{n}=8 ; \mathrm{SD}=1.36)$ compared to only 3.7 polyps in control colonies $(\mathrm{n}=26$; $\mathrm{SD}=0.87)$; at age $450 \mathrm{~d}$ control Nephthea sp. colonies had $269 \pm 212.0$ ( $\mathrm{n}=11$ ) polyps colony $^{-1}$, signifying continuation of exponential growth, whereas chimerical entities had an average of only $58.2 \pm 37.3(n=5)$ polyps colony ${ }^{-1}$, and showed signs of slower growth. The regression line for control colonies was significantly different from that for colonies associated with chimerical entities (Fig. 5). 


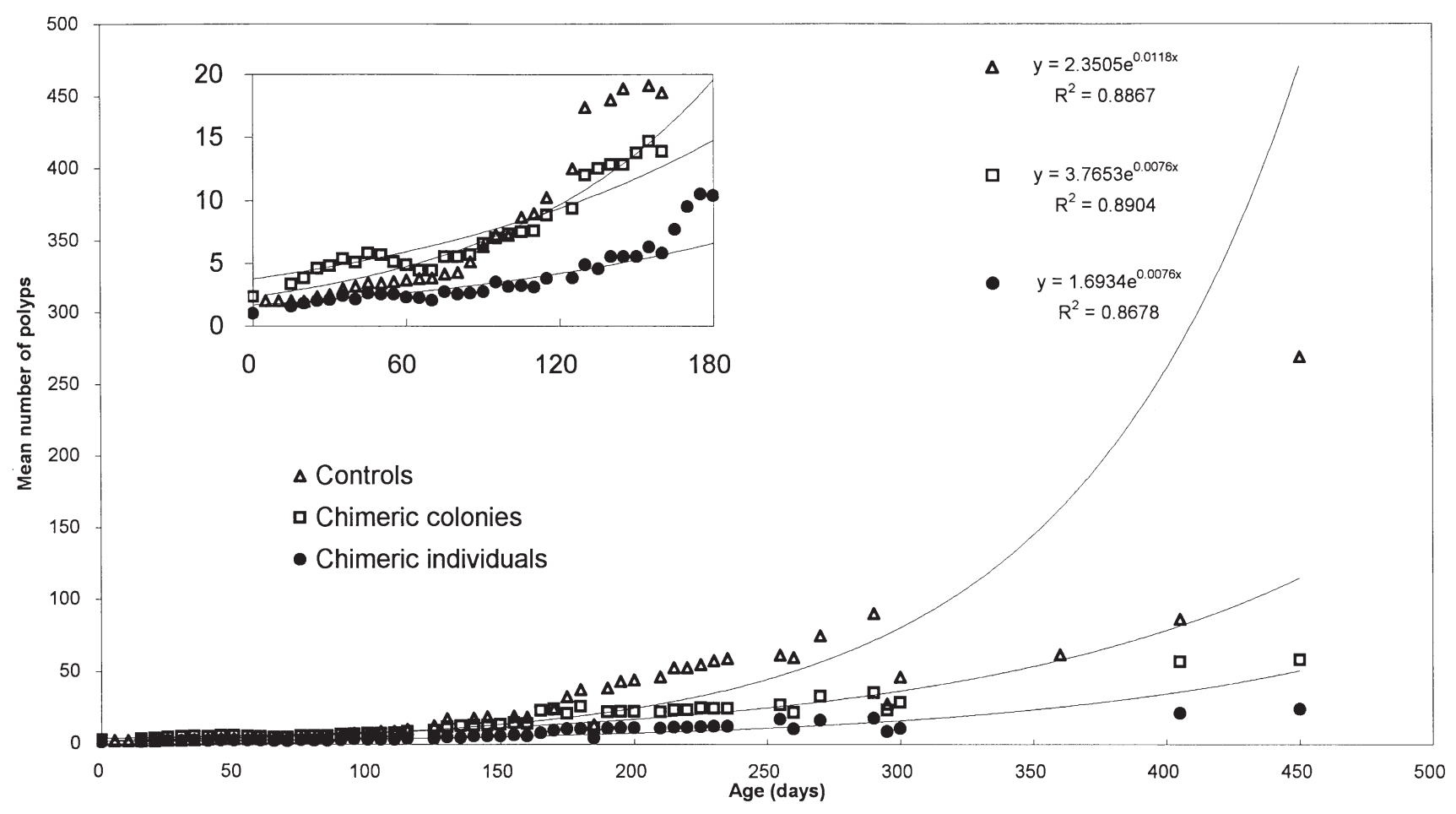

Fig. 5. Nephthea sp. Changes in mean number of polyps per individual in chimerical colonies, chimerical individuals and controls during $450 \mathrm{~d}$ observation. Inset: details of first $180 \mathrm{~d}$

\section{DISCUSSION}

The results of the present study reveal that tissue fusions between soft coral allogenic partners lead to the death of 1 or more partners (death directly related to the state of chimerism), to morphological resorption, disruption of polyp budding patterns, growth-retarding disorders in polyp structure, separation, and slower growth. No benefit from the state of chimerism was documented in the 4 soft corals studied. It is therefore clear that soft coral chimeras possess no long-term advantage over non-chimerical individuals and are likely to be less suited than non-chimerical individuals to in vitro conditions. In spite of our use of chimeras consisting of sibling planulae, we cannot rule out the possibility that an additional disadvantage of chimerism may be the cost of cell-lineage competition among allogenic incompatible lines and that an organism in a chimera could actually be parasitized by a member of its own species, as shown in other invertebrates (Pancer et al. 1995, Stoner \& Weissman 1996, Stoner et al. 1999).

Planulae of the species studied are reproduced sexually (Benayahu \& Loya 1983, Benayahu 1989, Achituv \& Benayahu 1990, Ben-David Zaslow 1994) and therefore are believed to be genetically different. Furthermore, we (Barki et al. 2000) have shown the presence of different AFLP (amplified fragment-length polymorphism) band patterns between sibling planulae of Pare- rythropodium fulvum fulvum, and that each planula has a unique genetic background. In the field, fast settlement and metamorphosis rates (Benayahu \& Loya 1983, Benayahu 1989, Ben-David Zaslow 1994) as well as gregarious settlement limit dispersion of kin larvae and may enhance the chances of chimera formation between sibling offspring (Ben-Shlomo et al. 2001).

The lack of a historecognition system in the early stages of ontogeny in the 4 soft coral species in our study is universally connoted. The results of fusion between young organisms confirm earlier findings on hard corals (Hidaka 1985, Frank et al. 1996), and suggest an ubiquitous pattern of alloimmune maturation in the Cnidaria.

Why then do chimeras form in the first place? Many invertebrates possess elaborate allorecognition systems that prevent the formation of chimeras, as do adult corals (Rinkevich 1996). However, although allorecognition is a very efficient system, it is not infallible. In particular, allorecognition systems in hard and soft corals are not functional during the early developmental stages (Hidaka 1985, Frank et al. 1997, Barki 1999, this study). The formation of chimeras in the early stages of development may, therefore, be a mere error in recognition arising from the limitations of an 'imperfect system' (Feldgarden \& Yund 1992).

Chimerism at an early age is promoted by the gregarious settlement of larvae characteristic of a number 
of coral species (literature documenting this phenomenon stretches back for more than a century: see Rinkevich \& Loya 1983). Planulae with a gregarious settlement mode may fuse by virtue of their physical proximity, regardless of selective advantage. Possibly the development of chimeras cannot be completely prevented by natural selection. Theoretically, selection could act in 2 ways to prevent fusion. It could accelerate maturation of the allorecognition system, or reduce gregarious settlement. The first may not be possible, since allorecognition systems require a certain minimum amount of time for ontogenetic discriminatory behaviour to develop. The costs of the second could outweigh its benefits, since gregarious settlement is often a facet of settlement site selection (Grosberg \& Quinn 1986). The Merriam-Webster dictionary describes a 'chimera' as 'a monster compounded of incongruous parts.' Our results strongly support this interpretation.

Acknowledgements. We thank Revital Ben-David Zaslow for unpublished information regarding the reproductive ecology of Nephthea. The staff of the H. Steinitz Marine Biology Laboratory in Eilat is acknowledged for diving facilities and hospitality. This study was done under the auspices of the Minerva Center for Marine Invertebrate Immunology and Developmental Biology.

\section{LITERATURE CITED}

Achituv Y, Benayahu Y (1990) Polyp dimorphism and functional, sequential hermaphroditism in the soft coral Heteroxenia fuscescens (Octocorallia). Mar Ecol Prog Ser 64: 263-269

Bancroft ID, Stevens A (1990) Theory and practice of histological techniques, 3rd edn. Churchill Livingstone, Edinburgh

Barki Y (1999) Aspects in the development, allorecognition responses and genetics in Red Sea soft corals. PhD thesis, Tel Aviv University

Barki Y, Douek J, Graur D, Gateño D, Rinkevich B (2000) Polymorphism in soft coral larvae revealed by amplified fragment-length polymorphism (AFLP) markers. Mar Biol 136: $37-41$

Benayahu Y (1989) Reproductive cycle and developmental processes during embryogenesis of Clavularia hamra (Cnidaria, Octocorallia). Acta Zool (Stockh) 70:29-36

Benayahu Y, Loya Y (1983) Surface brooding in the Red Sea soft

Editorial responsibility: Otto Kinne (Editor),

Oldendorf/Luhe, Germany coral Parerythropodium fulvum fulvum (Forskal). Biol Bull 165:353-369

Ben-David Zaslow R (1994) Longevity and competence of planulae of Octocorallia. MSc thesis, Tel Aviv University

Ben-Shlomo R, Douek J, Rinkevich B (2001) Heterozygote deficiency and chimerism in remote populations of a colonial ascidian from New Zealand. Mar Ecol Prog Ser 209:109-117

Bernischke K, Kaufmann P (1990) Pathology of the human placenta. Springer-Verlag, Berlin

Buss LW (1982) Somatic cell parasitism and the evolution of somatic tissue compatibility. Proc Natl Acad Sci USA 79: 5337-5341

Feldgarden M, Yund PO (1992) Allorecognition in colonial marine invertebrates: does selection favor fusion with kin or fusion with self? Biol Bull 182:155-158

Frank U, Bak RPM, Rinkevich B (1996) Allorecognition responses in the soft coral Parerythropodium fulvum fulvum from the Red Sea. J Exp Mar Biol Ecol 197:191-201

Frank U, Oren U, Loya Y, Rinkevich B (1997) Alloimmune maturation in the coral Stylophora pistillata is achieved through three distinctive stages, 4 months post-metamorphosis. Proc R Soc Lond Ser B Biol Sci 264:99-104

Gateño D, Barki Y, Rinkevich B (2000) Aquarium maintenance of reef octocorals raised from field collected larvae. Aquar Sci Conserv 2:227-236

Grosberg RK (1988) The evolution of allorecognition specificity in clonal invertebrates. Q Rev Biol 63:377-412

Grosberg RK, Quinn JF (1986) The genetic control and consequences of kin recognition by the larvae of a colonial marine invertebrate. Nature 322:456-459

Hidaka M (1985) Tissue compatibility between colonies and between newly settled larvae of Pocillopora damicornis. Coral Reefs 4:111-116

Pancer Z, Gershon H, Rinkevich B (1995) Coexistence and possible parasitism of somatic and germ cell lines in chimeras of the colonial urochordate Botryllus schlosseri. Biol Bull 189: 106-112

Rinkevich B (1996) Immune responsiveness in marine invertebrates revisited: the concourse of puzzles. In: Soderhall $K_{\text {, }}$ Vasta G, Iwanaga S (eds) New directions in invertebrate immunology. SOS Publications, Fair Haven, NJ, p 55-90

Rinkevich B, Loya Y (1983) Intraspecific competitive networks in the Red Sea coral Stylophora pistillata. Coral Reefs 1: 161-172

Rinkevich B, Shapira M (1999) Multi-partner urochordate chimeras outperform two-partner chimerical entities. Oikos 87:315-320

Stoner DS, Weissman IL (1996) Somatic and germ cell parasitism in a colonial ascidian: possible role for a highly polymorphic allorecognition system. Proc Natl Acad Sci USA 93: 15254-15259

Stoner DS, Rinkevich B, Weissman IL (1999) Heritable germ and somatic cell lineage competitions in chimeric colonial protochordates. Proc Natl Acad Sci USA 96:9148-9153

Submitted: May 8, 2001; Accepted: July 24, 2001

Proofs received from author(s): March 1, 2002 